Beattie, J. \& Herbert, P. H. (1947). Brit. F. Nutrit. I, 185.

Boothby, W. M. \& Sandiford, I. (1929). Amer. F. Physiol. 90, 290.

Burger, G. C. E., Sandstead, H. R. \& Drummond, J. (1945). Lancet, 249, 282.

Du Bois, D. \& Du Bois, E. F. (1916). Arch. intern. Med. 17, 865.

Du Bois, E. F. (1936). Basal Metabolism in Health and Disease, 3rd ed. London: Baillière, Tindall and Cox.

Lusk, G. (1928). The Elements of the Science of Nutrition, 4th ed., p. 65. Philadelphia and London: W. B. Saunders Co.

\title{
Nitrogen Balances during Recovery from Severe Undernutrition
}

\author{
By J. BEATTIE and PHILIPPA H. HERBERT (Leverhulme Scholar) \\ Bernhard Baron Research Laboratories, Royal College of Surgeons of England, \\ Lincoln's Inn Fields, London, W.C. 2 \\ AND D. J. BELL, Biochemical Laboratory, Cambridge
}

(Received 3× fuly 1947)

The results reported below were obtained on two groups of subjects, Group I in Western Holland in 1945 and Group II in the British Zone of Germany in 1946. Among the objects of the Dutch investigation was the determination of the calorieand protein-intake levels which would secure optimum nitrogen retention and rapid increase in weight in severely undernourished patients. The later work in Germany had as one of its objects the determination of the calorie and protein-nitrogen intakes necessary to secure nitrogenous equilibrium in subjects who were considerably wasted. They had lived on diets low in calories and protein over a period of about I year and were in slight negative nitrogen balance when first observed.

\section{METHODS}

The calorie and nitrogen contents of the daily intakes were estimated from food tables; for foodstuffs of British origin McCance \& Widdowson's (1942) tables were used. These were supplemented by values given by the Council of British Societies for Relief Abroad (1945) which contained more up-to-date information on wartime foods and especially on those of American origin. A third set of tables prepared by the Netherlands Food Administration (1944) during the German occupation was of great value in determining the composition of foodstuffs of Dutch origin, such as bread baked from locally produced flour, wartime cheeses and certain vegetables not included in the previous tables. Owing to the variations in the proportions of the cereals used in preparing the flour used for bread-and biscuit-making in Holland and for bread-making in Germany, it was necessary to carry out periodical analyses to 
obtain values for the nitrogen content of the flour and bread in the diet. In the German part of the work, the nitrogen content of each new diet was estimated by direct analysis to provide a check on the values obtained by tables. It was found that the estimated values for nitrogen content were within $\pm 3 \%$ of the values determined by analysis. This close approximation was due to the small number of standard foodstuffs used in the diets and to the constancy of their nitrogen content. No attempt was made to determine experimentally the calorie value of the daily diets.

Urine was collected over thymol and toluene for each period of $24 \mathrm{hr}$., care being taken to ensure exact timing of the complete sample. After acidification with a few drops of conc. sulphuric acid a portion of each $24 \mathrm{hr}$. specimen was taken and stored until analysed. Nitrogen was determined by a semi-micro Kjeldahl method using I ml. samples of urine and a selenium dioxide-copper sulphate catalyst. Digestion was continued with gentle boiling for at least $2 \mathrm{hr}$. after the mixture had cleared. No increase in ammonia titre was obtained by longer combustion. Agreement of duplicates was within $\mathbf{I} \%$. Duplicate determinations were not carried out simultaneously. Stools were brought to the laboratory in bed pans and were transferred to large glass jars containing about $250 \mathrm{ml}$. of water; $100 \mathrm{ml}$. of conc. sulphuric acid were added slowly with constant stirring. Additional stools were treated in the same way. When the complete sample had been collected, another $250 \mathrm{ml}$. conc. sulphuric acid were added to the entire mass. After cooling, the material was passed through a fine-wire sieve and distilled water added to give a known volume (approx. $500 \mathrm{ml}$. for each day's collection). The sample was agitated to ensure thorough mixing. Five portions, each about 10\% of the total sample, were taken. These were digested at boiling-point after addition of more sulphuric acid until solution was complete. From each, samples were taken and digested for varying lengths of time with sulphuric acid and catalyst until a constant maximal ammonia titre was obtained. The mean of these values from each portion was taken as the final figure.

Analyses of foodstuffs and diets were carried out by a process similar to that recorded for analysis of faeces.

Details of the composition of the diets are given in the Appendix (p. 217).

\section{RESULTS}

In Table I the intakes for each balance period are given. The balanice periods succeeded each other without any intervening 'free' days. Nitrogen losses in the faeces are set out in Table 2 and the balances for each period are contained in Table 3. Intakes, outputs and balances have been expressed in terms of Cal. and g. $\mathrm{N} / \mathrm{kg}$. body-weight. The body-weight used in the calculations was the mean value for each period.

In calculating average body-weights for each balance period, the mean weight was calculated from the daily weighings. In no balance period was the weight change between the first and last day of the period greater than $1.5 \mathrm{~kg}$., in most it was less than $\mathrm{I} \mathrm{kg}$.

The results for Groups I and II have been expressed graphically in Figs. I and 2, where the average daily nitrogen balances have been plotted against the average daily 
Table I. Dietary data for the two groups of subjects

\begin{tabular}{|c|c|c|c|c|c|c|}
\hline \multirow[b]{2}{*}{ Subject } & \multirow{2}{*}{$\begin{array}{l}\text { Balance } \\
\text { period } \\
\text { (days) }\end{array}$} & \multicolumn{3}{|c|}{ Average total daily intake } & $\begin{array}{r}\text { Average } d \\
\text { bod }\end{array}$ & $\begin{array}{l}\text { intake } / \mathrm{kg} \\
\text { eight }\end{array}$ \\
\hline & & $\begin{array}{l}\text { Type of } \\
\text { diet* }\end{array}$ & Calories & $\begin{array}{l}\text { Nitrogen } \\
\text { (g.) }\end{array}$ & Calories & $\begin{array}{l}\text { Nitrogen } \\
(\mathrm{g} .)\end{array}$ \\
\hline
\end{tabular}

Group I (Dutch):

$\begin{array}{lllllll}\text { J. } & \text { I6 } & \text { H. P. } & 3150 & 49 \cdot 7 & 76 \cdot 3 & \text { I.20 } \\ \text { E. } & \text { 13 } & \text { L.P. } & 2940 & 25 \cdot 5 & 52 \cdot 6 & 0.46 \\ & \text { Io } & \text { H.P. } & 3180 & 50 \cdot 2 & 55 \cdot 6 & 0.88 \\ \text { Z. } & \text { II } & \text { L.P. } & 2970 & 25 \cdot 4 & 64 \cdot 7 & 0.55 \\ \text { K. } & \text { 10 } & \text { L.P. } & 2980 & 25 \cdot 3 & 59 \cdot 7 & 0.51 \\ \text { V. } & \text { I0 } & \text { L.P. } & 2860 & 23 \cdot 8 & 61 \cdot 1 & 0.51 \\ \text { F. } & \text { 10 } & \text { Mx. } & 2910 & 39 \cdot 6 & 69 \cdot 2 & 0.94\end{array}$

Group II (German):

Ks.

Lv.

Wz.

$\mathrm{K} 1$.

Sc.

Gm.

Gd.

Gt.

Rs.

$\mathrm{Bm}$.

Ru.

10
15
10
10
13
12
12
10
15
10
10
13
10
15
10
10
13
10
15
10
10
13
10
15
10
10
15
10
10
13
10

10

10

15

10

I0

13

IO
$\mathrm{Mx}$.

Mx.

Mx.

Mx.

Mx.

$\mathrm{Mx}$.

Mx.

Mx.

Mx.

Mx.

Mx.

Mx.

$\mathrm{Mx}$.

Mx.

Mx.

Mx.

Mx.

Mx.

Mx.

$\mathrm{Mx}$.

Mx.

$\mathrm{Mx}$.

Mx.

Mx.

Mx.

Mx.

Mx.

Mx.

Mx.

$\mathrm{Mx}$.

Mx.

Mx.

$\mathrm{Mx}$.

Mx.

Mx.

$\mathrm{Mx}$.

Mx.

1890
2100
2220
2200
2520
2190
2000
1700
2100
2210
2190
2530

I 8 10

2090

2210

2190

$253^{\circ}$

1700

2080

2210

2160

2520

1700

2080

2140

1730

2090

2220

2200

$253^{\circ}$

$\mathrm{I} 720$

1710

2080

2200

2180

$253^{\circ}$

I 710

$10 \cdot 3$
$9 \cdot 8$
$13 \cdot 3$
$14 \cdot 6$
$19 \cdot 2$
$12 \cdot 7$
$11 \cdot 3$
$9 \cdot 1$
$10 \cdot 0$
$13 \cdot 2$
$14 \cdot 6$
$19 \cdot 2$

9.0

$9 \cdot 7$

I 3.2

$14 \cdot 5$

$19 \cdot 2$

8. 9

9.7

13.2

14.5

19.2

$9 \cdot 0$

$9 \cdot 6$

I3. I

$9 \cdot 2$

$9 \cdot 7$

$13 \cdot 3$

$14 \cdot 6$

I 9.2

$8 \cdot 9$

$9 \cdot 2$

$9 \cdot 7$

$13 \cdot 2$

14.5

19.2

9. I
33.8

$37 \cdot 7$

$39^{-1}$

$39^{\circ} \mathrm{I}$

43.9

39.5

37.5

3 I 7

38.9

$40 \cdot 6$

$40 \cdot 2$

$45^{\circ} 8$

30.6

$37 \cdot 2$

39.0

$38 \cdot 5$

43.9

33.5

$4 I \cdot I$

43.3

$42 \cdot 6$

$49 \cdot 2$

34.7

$42 \cdot 1$

$42 \cdot 5$

$3 I \cdot I$

$38 \cdot 0$

$40 \cdot 3$

$39^{\circ} 9$

$45 \cdot 7$

$35 \cdot 7$

34.9

$42 \cdot 3$

$43 \cdot 9$

$43 \cdot 2$

49. I

$3 I \cdot 7$
0. 8

0.18

0.23

0.26

0.33

0.23

0.21

0.17

0.185

0.24

0.27

0.35

0.16

0.17

0.23

0.26

0.33

O. 18

0.19

0.26

0.29

0.37

- 18

0.20

0.26

0.17

0.18

0.24

- 27

0.35

0.20

0.19

0.19

0.26

0.29

0.37

0.17

- See Appendix (p. 2r7). 
Table 2. Average values for faecal nitrogen of the two groups of subjects

Subject $\overbrace{\left.\begin{array}{c}\text { Calculated } \\ (10 \% \text { of intake })\end{array}\right) \text { Determined }}^{\text {Faecal nitrogen (g./day) }} \begin{gathered}\begin{array}{c}\text { Value used for } \\ \text { calculation of } \\ \text { balance }\end{array} \\ \text { balang }\end{gathered}$

Group I (Dutch):

\begin{tabular}{|c|c|c|c|}
\hline J. & 5.0 & 3.3 & 3.3 \\
\hline E. & $\begin{array}{l}2 \cdot 6 \\
5 \cdot 0\end{array}$ & $\begin{array}{l}3 \cdot 4 \\
4 \cdot I\end{array}$ & $\begin{array}{l}3 \cdot 4 \\
4 \cdot 1\end{array}$ \\
\hline Z. & 2.5 & I.5 & $x \cdot 5$ \\
\hline $\mathbf{K}$. & 2.5 & - & $2 \cdot 7^{*}$ \\
\hline V. & 2.4 & I.4 & $1 \cdot 4$ \\
\hline $\mathrm{F}$. & 4.0 & 1.8 & 1.8 \\
\hline
\end{tabular}

Group II (German):

Ks.

$1 \cdot 0$

$2 \cdot 3 \quad 2 \cdot 3$

$1 \cdot 0 \quad 1 \cdot 2 \quad 1 \cdot 2$

$1 \cdot 3 \quad I \cdot 3 \quad I \cdot 3$

$\mathrm{I} \cdot 5 \mathrm{I} \cdot 3$

$1 \cdot 9 \quad 1 \cdot 4 \quad I \cdot 4$

Lv. $\quad 0.9 \quad 2 \cdot 3 \quad 2 \cdot 3$

Wz. $\quad 0.9 \quad 2 \cdot 3 \quad 2 \cdot 3$

K.1. $\quad 0.9 \quad 2 \cdot 3 \quad 2 \cdot 3$

$1 \cdot 0 \quad I \cdot 2 \quad I \cdot 2$

$1 \cdot 3 \quad 1 \cdot 7 \quad 1 \cdot 7$

$1 \cdot 5 \quad 1 \cdot 7 \quad 1 \cdot 7$

$1.9 \quad-\quad 2.0$

Sc.

0.922 .020

$\begin{array}{lll}1 \cdot 0 & 1 \cdot 2 & 1 \cdot 2\end{array}$

I.3 - I.3

I.5 $\quad$ - $1 \cdot 5$

1.92 .025

Gm. $\quad 0.9 \quad 1.2 \quad 1.2$

I.O $\quad-\quad I \cdot 2$

I'3 $2.0 \quad 2.0$

$\mathrm{I} \cdot 5 \quad \mathrm{I} \cdot 7 \quad \mathrm{I} \cdot 7$

$1 \cdot 9 \quad 2.0 \quad 2 \cdot 0$

Gt.

$0.925 \cdot 0$

$\begin{array}{lll}1 \cdot 0 & I \cdot 2 & I \cdot 2\end{array}$

$\mathrm{I} \cdot 3 \quad-\quad \mathrm{I} \cdot 3$

Rs.

$0.922 .0 \quad 2.0$

$\begin{array}{lll}I \cdot 0 & 0.7 & 0.7\end{array}$

$1 \cdot 3 \quad-\quad 1 \cdot 3$

$I \cdot 5 \quad-\quad I \cdot 5$

I.9 I.9 I.9

Gd. $\quad 0.9 \quad 2.0 \dagger$

Bm. $\quad 0.9 \quad 2.0+$

$\begin{array}{rrr}1.0 & 1.5 & 1.5 \\ 1.3 & .1 .6 & 1.6\end{array}$

$1 \cdot 5 \quad 1 \cdot 6 \quad 1 \cdot 6$

$1 \cdot 9 \quad \mathrm{I} \cdot 6 \quad \mathrm{I} \cdot 6$

$\mathrm{Ru}$.

0.9

I.9

$r \cdot 9$

* This value was obtained from a preceding short balance period with a comparable diet.

$\dagger$ Assumed, as this was the loss obtained in patients Sc., Gt. and Rs. with the same diet as that eaten by $\mathrm{Gd}$. and $\mathrm{Bm}$. 
Table 3. Average nitrogen balances of the two groups of subjects

\begin{tabular}{|c|c|c|c|c|c|}
\hline \multirow[b]{2}{*}{ Subject } & \multirow{2}{*}{$\begin{array}{c}\text { Nitrogen } \\
\text { intake } \\
\text { (g./day) }\end{array}$} & \multirow{2}{*}{$\begin{array}{c}\text { Nitrogen } \\
\text { output in } \\
\text { urine } \\
\text { (g./day) }\end{array}$} & \multicolumn{2}{|c|}{ Nitrogen balance } & \multirow{2}{*}{$\begin{array}{c}\text { Average } \\
\text { body-wt. } \\
\text { (kg.) }\end{array}$} \\
\hline & & & g./day & $\begin{array}{l}\text { g./kg. body-wt./ } \\
\text { day }\end{array}$ & \\
\hline \multicolumn{6}{|c|}{ Group I (Dutch): } \\
\hline $\mathrm{J}$. & $49 \cdot 7$ & $36 \cdot 6$ & +9.8 & +0.237 & $40 \cdot 0$ \\
\hline E. & $\begin{array}{l}25 \cdot 5 \\
50 \cdot 2\end{array}$ & $\begin{array}{l}17 \cdot 6 \\
35 \cdot 9\end{array}$ & $\begin{array}{l}+4.5 \\
+10 \cdot 2\end{array}$ & $\begin{array}{l}+0.08 \mathrm{I} \\
+0.178\end{array}$ & $\begin{array}{l}55 \cdot 9 \\
57 \cdot 2\end{array}$ \\
\hline$Z$. & $25 \cdot 4$ & $18 \cdot 0$ & +5.9 & +0.129 & $45^{\circ} 9$ \\
\hline $\mathrm{K}$. & $25 \cdot 3$ & $17 \cdot 0$ & $+5 \cdot 6$ & +0.112 & $50 \cdot 0$ \\
\hline v. & $23 \cdot 8$ & $14 \cdot 1$ & $+8 \cdot 3$ & +0.178 & $46 \cdot 8$ \\
\hline F. & $39 \cdot 6$ & $30 \cdot 0$ & $+7 \cdot 8$ & +0.186 & $42 \cdot 0$ \\
\hline
\end{tabular}

Group II (German):

Ks.

Lv.

Wz.

$\mathrm{K} 1$.

Sc.

Gt.

Gd.

Bm.

$\mathrm{Ru}$.

Gm.

Rs.

10.3
$9 \cdot 8$
13.3
14.6
19.2

$12 \cdot 7$

$11 \cdot 3$

$9 \cdot I$

10.0

$13 \cdot 2$

ז. 6

$19 \cdot 2$

9.0

$9 \cdot 7$

I 3.2

I $4 \cdot 5$

I 9.2

8.9

$9 \cdot 7$

I 3.2

14.5

19.2

9.0
9.6

13.1

$9 \cdot 2$

$9 \cdot 7$

13.3

$14 \cdot 6$

19.2

8.9

$9 \cdot 2$

$9 \cdot 7$

I 3.2

14.5

19.2

$9^{\cdot} \mathrm{I}$

\section{$7 \cdot 8$}

6.9

$9 \cdot 7$

I 3.0

15.4

$9 \cdot 3$

$0 \cdot 0$

$6 \cdot 4$

$5 \cdot 8$

8.0

I0. 5

$12 \cdot 5$

$7 \cdot 8$

7.0

$9 \cdot 6$

II. 5

I $3 \cdot 8$

$7 \cdot 2$

$6 \cdot 6$

8.7

10.6

I. I

$6 \cdot 7$

6.3

8.6

$7 \cdot 5$

$7 \cdot 3$

10.0

$12 \cdot 4$

15.0

$7 \cdot 4$

6.8

$6 \cdot 4$
$9 \cdot 2$

II' I

14.4

9.0
$+0.2$

$+\mathrm{I} \cdot 7$

$+2 \cdot 3$

$+0.3$

$+2 \cdot 3$

$+\mathrm{I} \cdot \mathrm{I}$

0

$+0.4$

$+3.0$

$\begin{array}{r}+35 \\ \hline\end{array}$

$+2 \cdot 4$

$\begin{array}{r}+47 \\ \hline\end{array}$

$-0.8$

$\begin{array}{r}+1.5 \\ \hline\end{array}$

$+2 \cdot 3$

$\begin{array}{r}+\quad 1.5 \\ \hline\end{array}$

$+3.4$

$+0.5$

$\begin{array}{r}+\quad \mathbf{1} \cdot 9 \\ \hline\end{array}$

+2.5
+

$+2 \cdot 2$

$+3 \cdot \mathrm{I}$

$+0.3$

$+2 \cdot \mathrm{I}$

$+3 \cdot 1$

$-0.3$

$+\quad 1.7$

$+2 \cdot 0$
$+\quad 07$

$\begin{array}{r}+0.7 \\ \hline\end{array}$

$+2 \cdot 3$

$-0.5$

$+0.4$

$+\quad \mathrm{I} .8$

$+2.4$

+
$+\quad 8$

$+3.2$

$-\mathrm{I} \cdot 8$
$+0.004$

$+0.030$

$+0.040$

$+0.005$

$+0.041$

$+0.019$

0

$+0.007$

$+0.055$

$+0.064$

$+0.044$

$+0.085$

$-0.013$

$+0.027$

$+0.039$

$+0.027$

$+0.059$

$+0.010$

$+0.038$

$+0.048$

$+0.044$

$+0.06 \mathrm{I}$

$+0.007$

$+0.042$

$+0.062$

$-0.005$

$+0.03 \circ$

$+0.036$

$+0.012$

$+0.040$

$-0.009$

$+0.008$

$+0.036$

$+0.048$

$+0.036$

$+0.063$

$-0.035$ $55^{\circ} 9$

$55^{\circ} 9$

57.0

$56 \cdot 2$

$57 \cdot 4$

$55^{\circ} 5$

53.5

$53 \cdot 5$

53.9

$54^{\circ} 5$

$54 \cdot 6$

$55 \cdot 2$

$56 \cdot 0$

$56 \cdot 2$

$56 \cdot 7$

$57^{\circ} \circ$

$57 \cdot 6$

$50 \cdot 6$

50.5

$51 \cdot 0$

50.8

5 I' 3

$48 \cdot 9$

$49 \cdot 4$

$50 \cdot 3$

$55 \cdot 5$

$55^{\circ} \mathrm{O}$

$52 \cdot 2$

$55^{\circ} 0$

$55 \cdot 3$

$45 \cdot 6$

$49 \cdot 1$

$49 \cdot 2$

$50 \cdot 1$

50.4

5 I. 4

$54 \cdot 1$ 


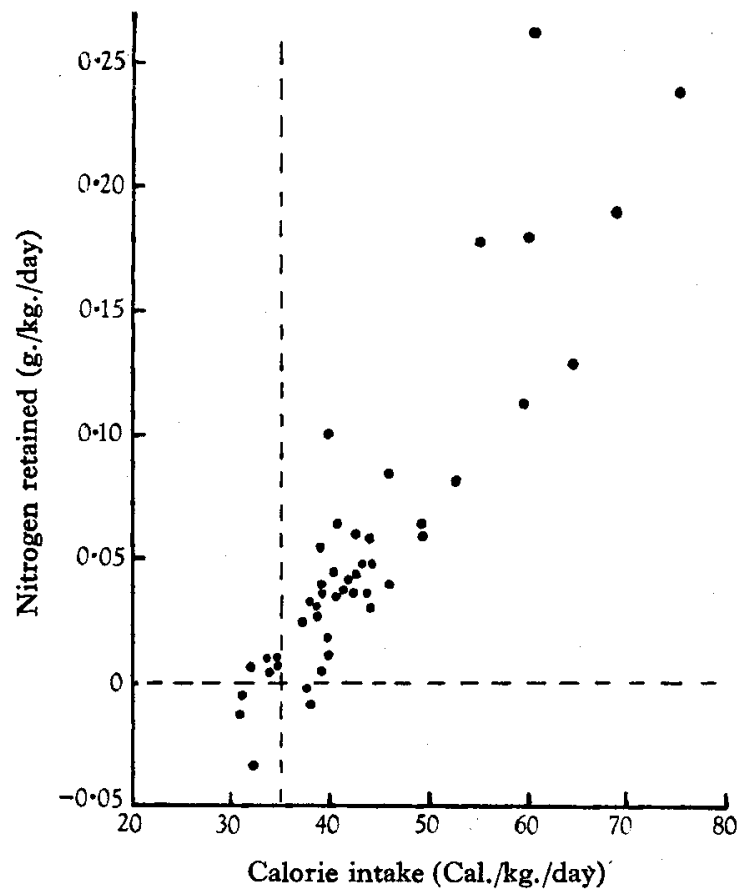

Fig. I. Relation between calorie intake expressed as Cal./kg. body-weight/day and the nitrogen retention expressed as $\mathrm{g} . / \mathrm{kg}$. body-weight/day. Balance periods of $\mathrm{r} 0$ days and over. For the meaning of the vertical broken line see p. 208 .

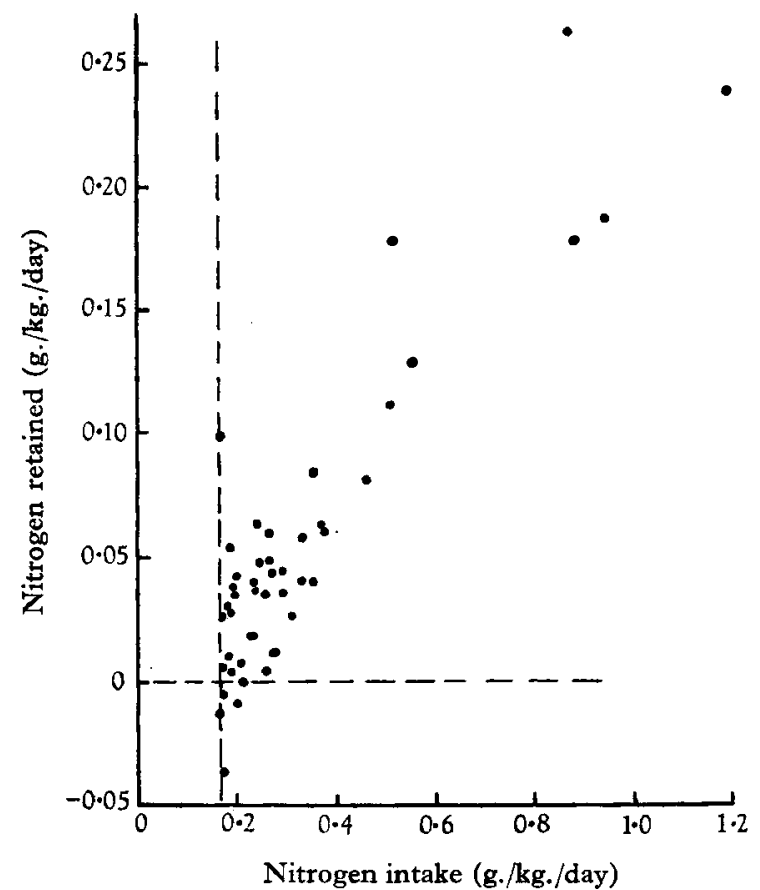

Fig. 2. Relation between nitrogen intake expressed as g./kg. body-weight/day and the nitrogen retention similarly expressed. Balance periods of 10 days and over. For the meaning of the vertical broken line see p. 208 . 
calorie and nitrogen intakes for each balance period. Fig. 3 has been plotted to show average daily balances against calorie intakes between 30 and $40 \mathrm{Cal} / \mathrm{kg}$. Beside each point is the average nitrogen intake of each period. The relation between calorie intakes above $42.5 \mathrm{Cal} . / \mathrm{kg}$. and nitrogen retention has been plotted in Fig. 4. Nitrogen intakes in g./kg./day are indicated beside each point. Table 4 and Fig. 4 contain values obtained during short balance periods of $4^{-6}$ days in our Dutch series. These are indicated by $\otimes$ on the graph. Nitrogen intakes are also placed against each point.

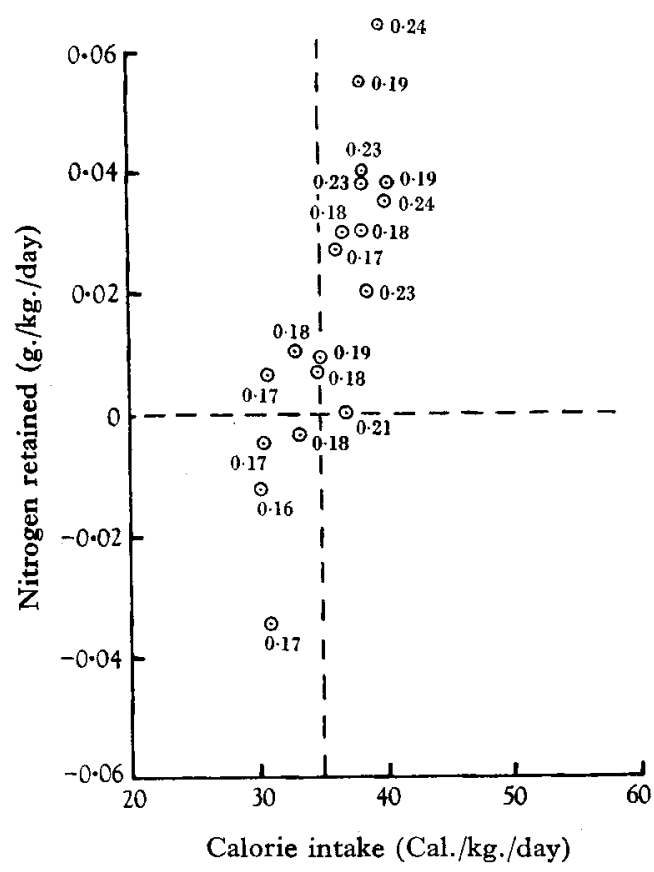

Fig. 3. Nitrogen retention as related to calorie and nitrogen intakes less than $42 \cdot 5 \mathrm{Cal} . / \mathrm{kg}$. body-weight/ day and $0.24 \mathrm{~g} . \mathrm{N} / \mathrm{kg}$. body-weight/day. The sign of the nitrogen balance is determined by the calorie intake. Balance periods of ro days and over. Figures beside each point indicate the average nitrogen intake in $\mathrm{g} . / \mathrm{kg}$./day. For the meaning of the vertical broken line see below on this page.

Fig. I. suggests that nitrogen retention is roughly proportional to calorie intake. The graph, however, indicates that there is a critical calorie intake level around $30-40 \mathrm{Cal} . / \mathrm{kg}$. where the level of the nitrogen intake determines the sign and magnitude of the balance. It would appear from Fig. 2 that at nitrogen intake levels above $0.2 \mathrm{~g} . / \mathrm{kg}$. / day the balance is always positive. At high intake levels, those above $0.3 \mathrm{~g} . / \mathrm{kg}$., the points seem to show a shift to the right indicating that retention at such levels is not proportional to the nitrogen intake.

At the critical lower level of intake of $30-40 \mathrm{Cal} / \mathrm{kg}$./day it would appear (Fig. 3) that it is possible to obtain significant positive nitrogen balances on nitrogen intakes as low as $0.17 \mathrm{~g} . / \mathrm{kg}$., provided the calorie intake exceeds $35 \mathrm{Cal} . / \mathrm{kg}$. Allowing for inherent errors in the balance values it would be justifiable to conclude that nitrogen equilibrium in our emaciated subjects was attained when the calorie intake was no 
Vol. I

less than $35 \mathrm{Cal} . / \mathrm{kg}$. and the nitrogen intake not less than $0.17 \mathrm{~g} . / \mathrm{kg}$. If one or other of these intakes were less a negative nitrogen balance might be expected.

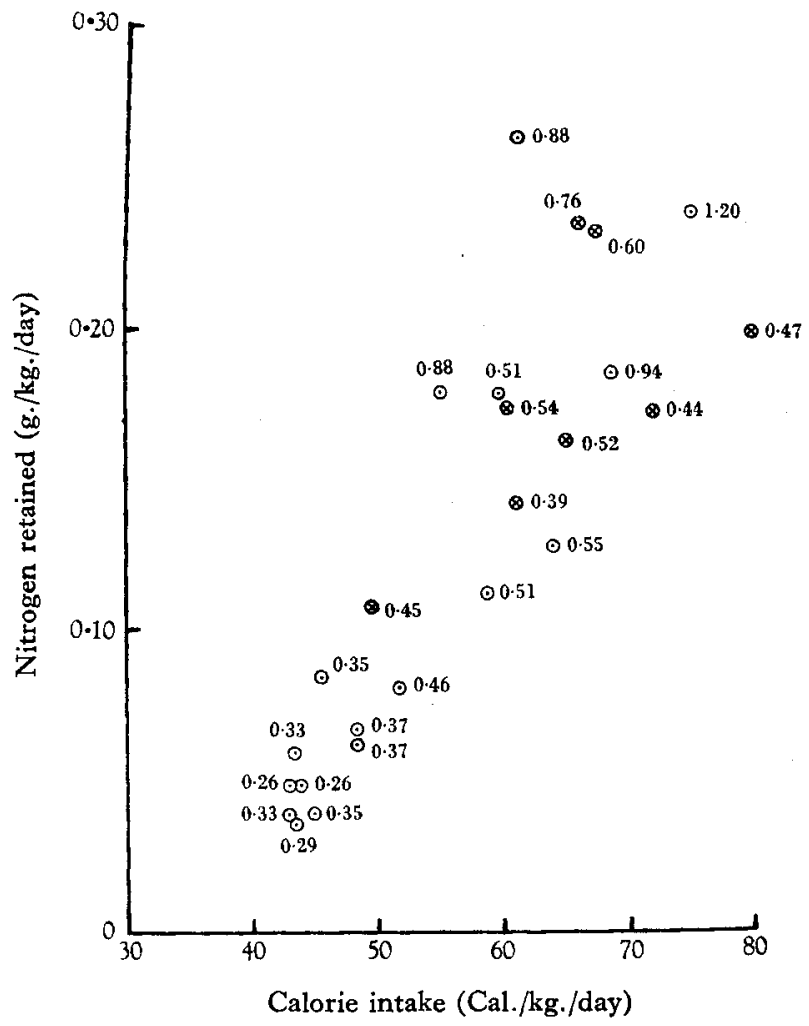

Fig. 4. Nitrogen retention as related to calorie and nitrogen intakes above $42 \cdot 5 \mathrm{Cal} . / \mathrm{kg}$. body-weight/ day and $0.24 \mathrm{~g}$. N/ $\mathrm{kg}$. body-weight/day. Balance periods of less than ro days are indicated thus $\otimes$. The figures beside each point indicate the average nitrogen intake in $\mathrm{g} . / \mathrm{kg} . / \mathrm{day}$.

Table 4. Average values obtained in short balance periods (Dutch group)

\begin{tabular}{|c|c|c|c|c|c|c|}
\hline \multirow[b]{3}{*}{ Subject } & \multirow[b]{3}{*}{$\begin{array}{c}\text { Type of } \\
\text { diet* }\end{array}$} & \multirow{3}{*}{$\begin{array}{c}\text { Balance } \\
\text { period } \\
\text { (days) }\end{array}$} & \multirow{2}{*}{\multicolumn{2}{|c|}{$\begin{array}{c}\text { Daily intake/kg. body- } \\
\text { weight }\end{array}$}} & \multicolumn{2}{|c|}{ Nitrogen retained } \\
\hline & & & & & 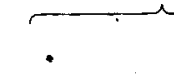 & As per- \\
\hline & & & Calories & $\begin{array}{l}\text { Nitrogen } \\
\text { (g.) }\end{array}$ & $\begin{array}{l}\text { g./kg. body- } \\
\text { weight/day }\end{array}$ & $\begin{array}{l}\text { nitrogen } \\
\text { absorbed }\end{array}$ \\
\hline T. Jr. & M. & 5 & $49 \cdot 6$ & 0.44 & $0 \cdot 106$ & 24 \\
\hline T. Sr. & H. & 6 & $62 \cdot 3$ & 0.38 & $0.14 I$ & 37 \\
\hline d. G. & M. & 6 & $66 \cdot 2$ & 0.58 & 0.167 & 29 \\
\hline v. d. H. & H. & 6 & $71 \cdot 3$ & 0.43 & 0.156 & 36 \\
\hline B. & M. & 6 & $62 \cdot 3$ & 0.55 & 0.201 & 37 \\
\hline$T$ & H. & 5 & $80 \cdot 3$ & 0.48 & 0.195 & $4 I$ \\
\hline v. A. & M. & 5 & $68 \cdot 1$ & 0.60 & 0.222 & 37 \\
\hline $\mathrm{Bg}$. & H. P. & 4 & $67 \cdot 7$ & 0.76 & 0.235 & 23 \\
\hline
\end{tabular}

\footnotetext{
* See Appendix (p. 217 ).
} 
Examination of Fig. 4 reveals that at certain retention levels, where there is only a small difference in the calorie intake $/ \mathrm{kg}$., there is a wide variation in the nitrogen intake $/ \mathrm{kg}$., e.g. at calorie intakes between 67 and $76.5 \mathrm{Cal} / \mathrm{kg}$./day, the nitrogen retention was between 0.23 and $0.24 \mathrm{~g}$. N/kg./day but the nitrogen intakes varied between 0.6 and $1.2 \mathrm{~g} . \mathrm{N} / \mathrm{kg}$./day. These and other similar examples in the figure suggest that in some diets a considerable proportion of the dietary protein was being used as a source of energy. It is conceivable that the ratio of non-protein to protein calories in the diet may

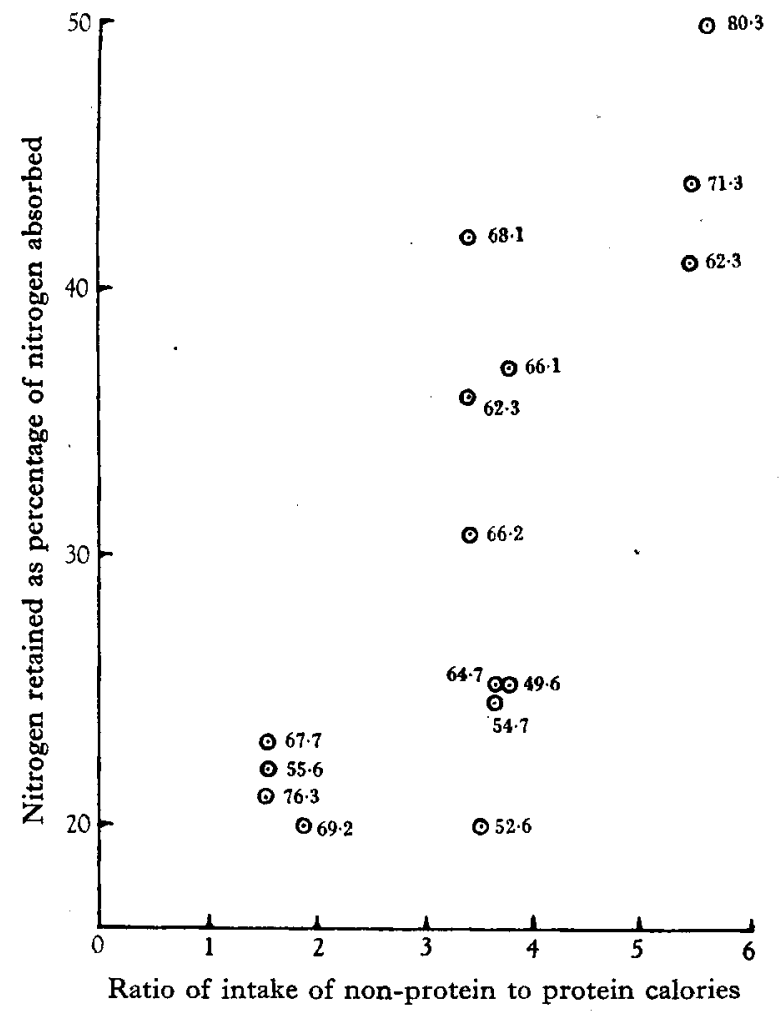

Fig. 5. Relation between intake of protein and non-protein calories and nitrogen retention (Dutch series). The figures beside each point indicate calorie intakes expressed as Cal./kg. body-weight/ day.

have had some influence on the level of nitrogen retention. Where there was a high proportion of non-protein calories there may have been a marked protein-sparing action and consequently a better nitrogen retention.

Table 5 gives average nitrogen retentions and intakes of protein and non-protein calories of the two groups of subjects, while Fig. 5 shows the nitrogen retention in Group I (with the eight balance periods in Table 4) on different ratios of non-protein to protein calories in the diet. The calorie intake levels expressed as $\mathrm{Cal} . / \mathrm{kg}$./day are shown alongside each point. Four periods, where the non-protein/protein ratios were between $I^{\prime} 5$ and $2 \cdot 0$, gave retentions between $2 \mathrm{I}$ and $23 \%$. These periods where the non-protein/protein ratio was $5.4-5.5$ gave retentions between 40 and $50 \%$. The intermediate ratios were around 3.5 . In them there was an exceedingly wide range of 
Table 5. Average nitrogen retention and intake of protein and non-protein calories of the two groups of subjects

\begin{tabular}{|c|c|c|c|c|c|c|c|}
\hline \multirow[b]{2}{*}{ Subject } & \multirow[b]{2}{*}{$\begin{array}{c}\text { Nitrogen } \\
\text { absorbed } \\
\text { (g./day) }\end{array}$} & \multicolumn{2}{|c|}{ Nitrogen retained } & \multicolumn{3}{|c|}{ Energy intake } & \multirow[b]{2}{*}{$\begin{array}{c}\text { Ratio of } \\
\text { intake of } \\
\text { non-protein } \\
\text { to protein } \\
\text { calories }\end{array}$} \\
\hline & & (g./day) & $\begin{array}{l}\text { As per- } \\
\text { centage of } \\
\text { nitrogen } \\
\text { absorbed }\end{array}$ & $\begin{array}{c}\text { Total } \\
\text { (Cal./day) }\end{array}$ & $\begin{array}{c}\text { From } \\
\text { protein } \\
\text { (Cal./day) }\end{array}$ & $\begin{array}{l}\text { From non- } \\
\text { protein } \\
\text { sources } \\
\text { (Cal./day) }\end{array}$ & \\
\hline
\end{tabular}

Group I (Dutch):

\begin{tabular}{|c|c|c|c|c|c|c|c|}
\hline J. & $46 \cdot 4$ & $9 \cdot 8$ & $2 \mathrm{I}$ & 3150 & 1270 & 1880 & $1 \cdot 5$ \\
\hline E. & $22 \cdot I$ & 4.5 & 20 & $294^{\circ}$ & $65^{\circ}$ & 2290 & 3.5 \\
\hline & $46 \cdot 1$ & $10 \cdot 2$ & 22 & 3180 & 1290 & 1890 & I.5 \\
\hline $\begin{array}{l}\text { Z. } \\
\text { K. }\end{array}$ & 23.9 & 5.9 & 25 & 2970 & $65^{\circ}$ & 2320 & 3.6 \\
\hline $\begin{array}{l}\text { K. } \\
\text { V. }\end{array}$ & $22 \cdot 6$ & $5 \cdot 6$ & 25 & 2990 & $65^{\circ}$ & 2340 & $3^{3.6}$ \\
\hline V. & $22 \cdot 4$ & $8 \cdot 3$ & 37 & 2860 & 610 & 2250 & 3.7 \\
\hline F. & $37 \cdot 8$ & $7 \cdot 8$ & $2 \mathrm{I}$ & 2910 & 1010 & 1900 & I.9 \\
\hline T. Jr. & 18.9 & $4 \cdot 8$ & 25 & 2360 & 510 & 1850 & $3 \cdot 7$ \\
\hline T. Sr. & $16 \cdot 2$ & $6 \cdot 7$ & $4 \mathrm{I}$ & $293^{\circ}$ & 460 & $247^{\circ}$ & 5.4 \\
\hline d. G. & $27 \cdot I$ & $8 \cdot 3$ & $3 I$ & 3360 & 760 & 2600 & 3.4 \\
\hline v. d. H. & $16 \cdot 1$ & $7^{\circ} \circ$ & 44 & $293^{\circ}$ & 460 & 2470 & $5 \cdot 4$ \\
\hline B. & $26 \cdot 7$ & 9.5 & 36 & 3360 & 760 & 2600 & $3 \cdot 4$ \\
\hline T. & 14.4 & $7 \cdot 2$ & 50 & $293^{\circ}$ & 450 & 2480 & 5.5 \\
\hline v. A. & 25.5 & $10 \cdot 6$ & 42 & 3090 & 700 & 2390 & 3.4 \\
\hline Bg. & $47 \cdot 4$ & II'O & 23 & 3170 & 1280 & I 890 & $1 \cdot 5$ \\
\hline
\end{tabular}

Group II (German):

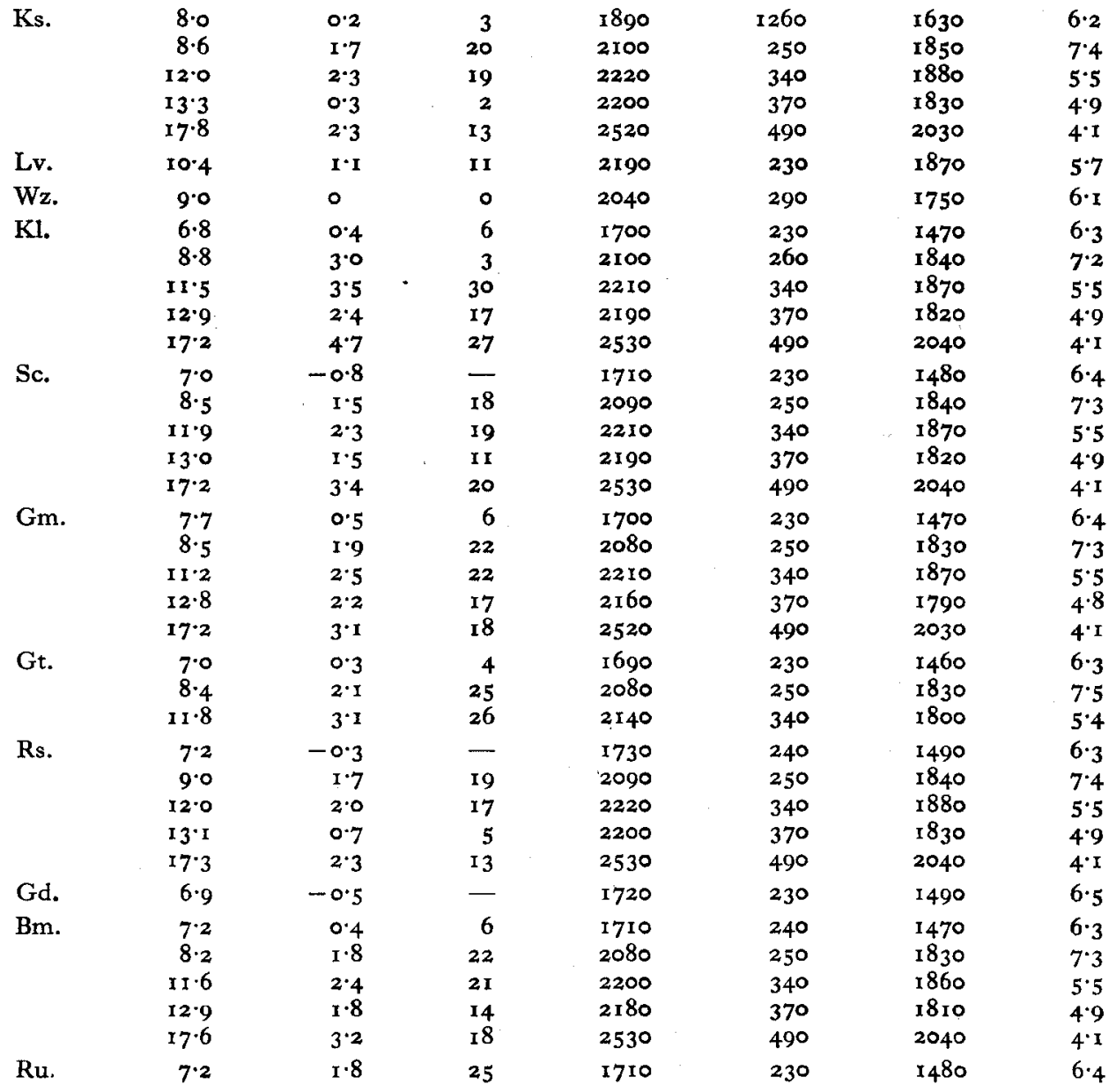


percentage retentions, 20-42. It was clear, therefore, that while the protein-sparing action appeared to be present in some balance periods with a high non-protein/protein ratio, it would not have accounted for the wide variation in the intermediate-ratio (3.5) diets. The level of calorie intake may have an influence, but obviously other factors must operate.

\section{DISCUSSION}

As Beattie \& Herbert (1947) have shown that in the early phases of recovery the metabolic level rises with the calorie intake, it seemed possible that a rise in this level might affect adversely the nitrogen retention. Table 6 gives the relevant data. The

Table 6. Average values for nitrogen retention and basal heat production of the two groups of subjects

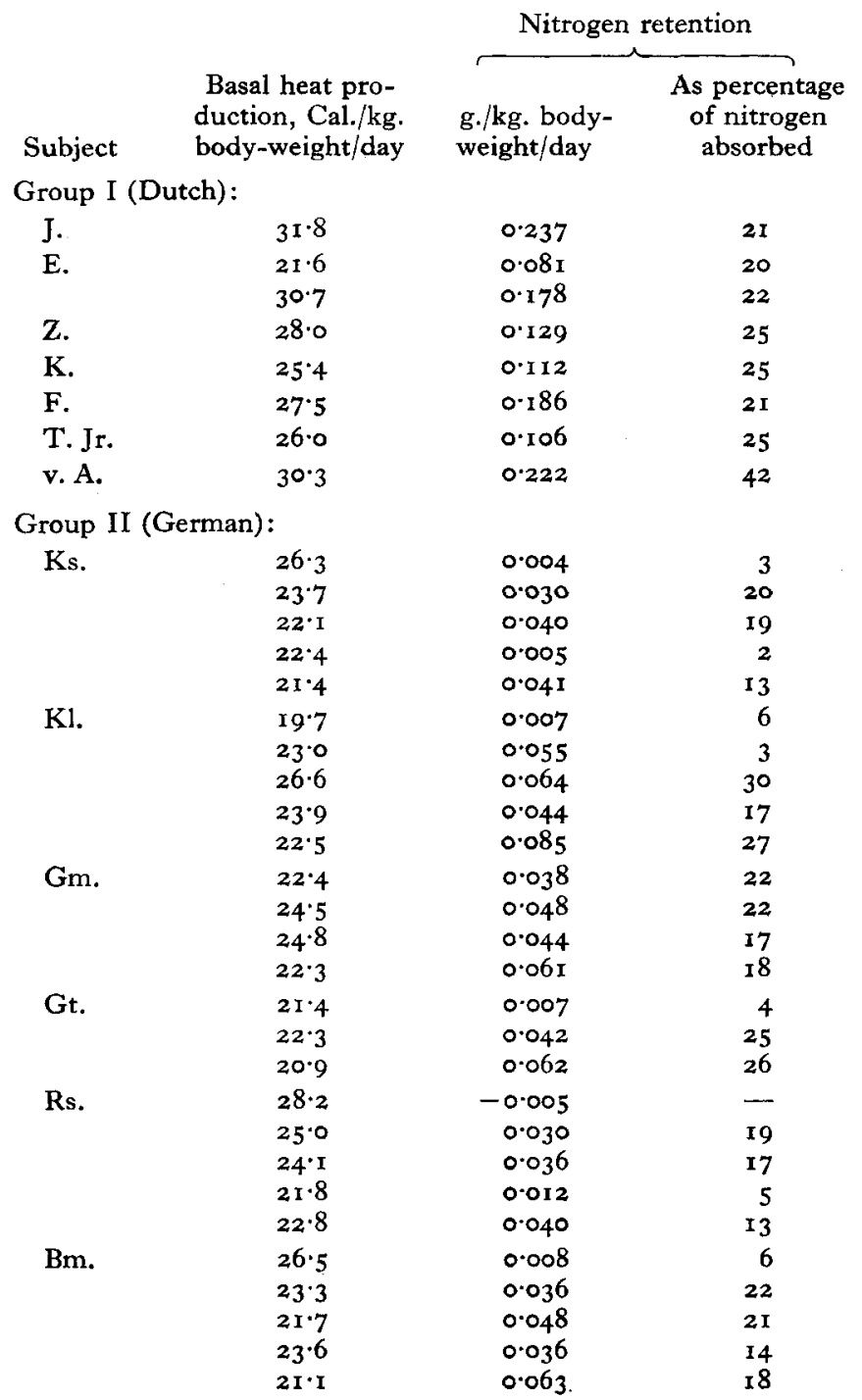


relation of metabolic level to retention for both the Dutch and German groups is given graphically in Fig. 6. It would appear that retention increased with the rise in metabolic level. This relation, however, may be merely a reflexion of the high calorie and nitrogen intakes-absolute retentions rising as more nitrogen is available in the diet. There is, however, no indication that a high metabolic level necessarily leads to a reduction in the absolute values of nitrogen retention. When the metabolic level is plotted against percentage nitrogen retention there is no conclusive evidence that these two factors are causally related (Fig. 7).

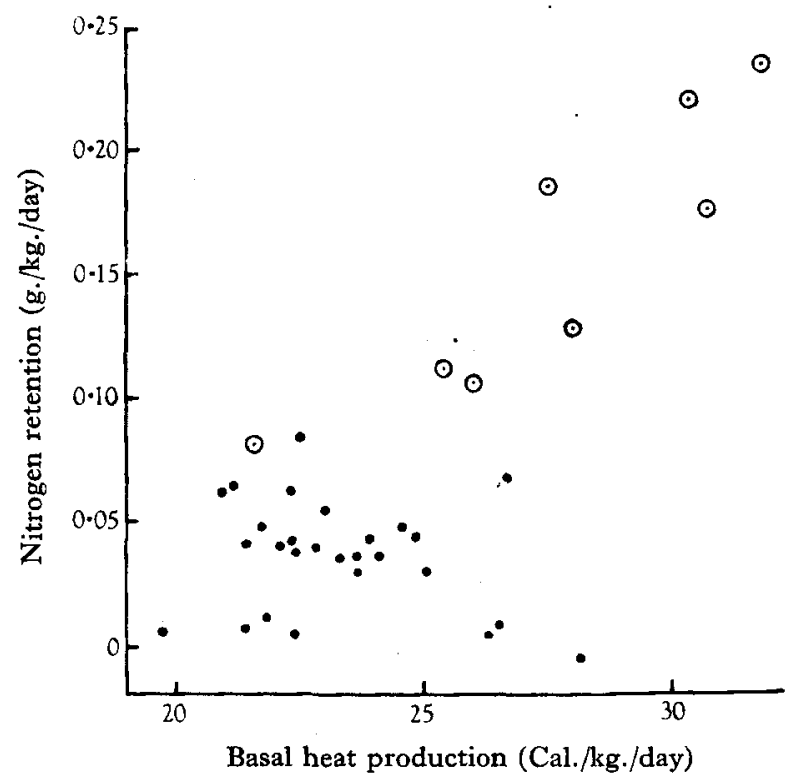

Fig. 6. Relation between the basal heat production expressed as Cal./kg. body-weight/day and nitrogen retention expressed as $\mathrm{g}$. N/kg. body-weight/day. Dutch series $\odot$; German series $\bullet$. Dutch series includes only first balance period. German series includes all balance periods.

In the German group (Group II) the calorie intakes were confined to a relatively narrow range. It was observed by Beattie \& Herbert (1947) that these subjects showed relatively small variations in their metabolic levels. The nitrogen intakes in these men were restricted and consequently errors in estimating their nitrogen retentions were proportionately higher than for Group I where the nitrogen intakes were greater. It is none the less remarkable that the percentage nitrogen retention should show no relation to the non-protein/protein ratio (Fig. 8). Apparently the low calorie- and protein-intake level in these men, coming, as it did, very close to their maintenance levels in the early diet periods, provided a narrow and variable margin for conservation, too narrow for the protein-sparing action of non-protein calories to be apparent.

One further aspect of nitrogen retention seemed worthy of study. It seemed possible that, on the high levels of calorie intake with consequent increase in metabolic level during the early phase of recovery, the carbohydrate utilization might not be complete owing to a relative deficiency in vitamin $B_{1}$. Utilization beyond the pyruvate stage might be prevented with a consequent demand for more carbohydrate which 
would only be satisfied by the de-amination of amino-acids and the conversion of the carbon skeletons into glycogen. Such an effect would diminish the nitrogen available for retention. Table 7 provides the necessary data. All these patients were on diets in which the main vitamin $B_{1}$ intake was derived from skim milk powder of a known vitamin $B_{1}$ content and from glucose which had been reinforced by the addition of synthetic vitamin $B_{1}$ in the proportion of $1.33 \mathrm{mg} / / 100 \mathrm{~g}$. glucose.

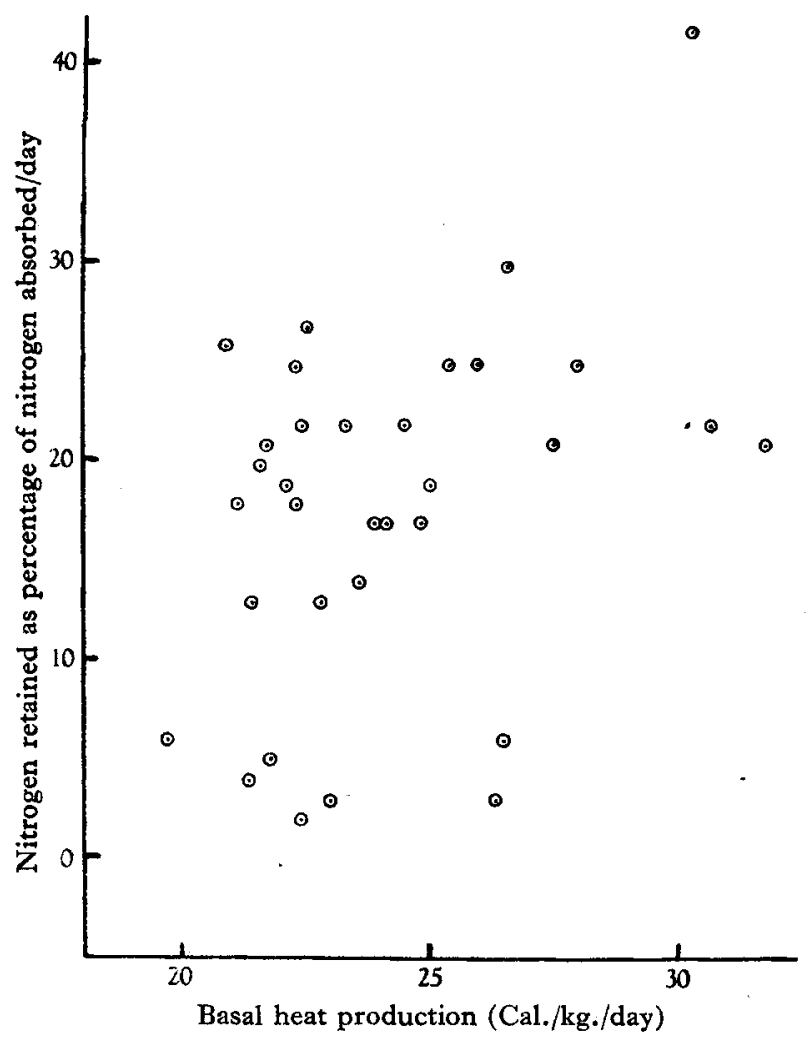

Fig. 7

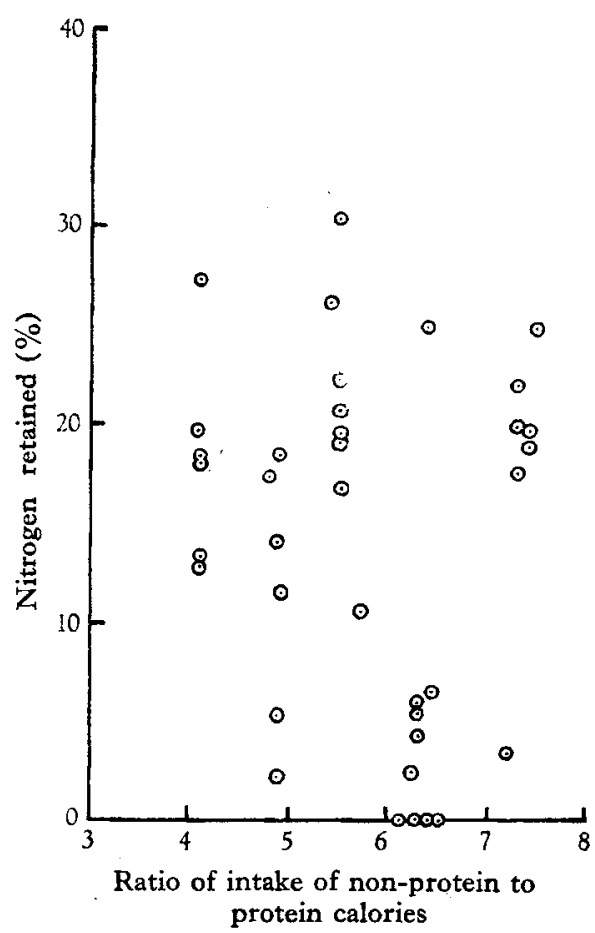

Fig. 8

Fig. 7. Relation between the basal heat production expressed as Cal./kg. body-weight/day and nitrogen retention expressed as percentage of nitrogen absorption (German and Dutch series).

Fig. 8. Relation between intake of protein and non-protein calories and nitrogen retention (German series).

The diets which were relatively poor in vitamin $B_{1}$ were those with a high protein content of about $5 \circ \mathrm{g}$. $\mathrm{N} /$ day. The diets richest in vitamin $\mathrm{B}_{1}$ were those containing only $\mathrm{I} 8 \mathrm{~g}$. $\mathrm{N} /$ day. The non-protein calorie intake in the latter group was obtained exclusively from the reinforced glucose. This combination was unfortunate, for the diets with a low non-protein/protein ratio were those with a low vitamin $B_{1}$ content and those with a high non-protein/protein ratio were richest in the vitamin. When nitrogen retention as $\mathrm{g}$. $\mathrm{N} / \mathrm{kg}$./day is compared with the vitamin $\mathrm{B}_{1}$ intake expressed either as $\mathrm{mg} . / \mathrm{kg}$./day or as $\mathrm{mg} . / 1000 \mathrm{Cal} . /$ day, it would appear that nitrogen retention was not related to the intake of vitamin $B_{1}$ (Fig. 9A and B). Examination of Table 7 
shows that three of the diets contained less than the Cowgill (1934) standard requirement calculated from the formula

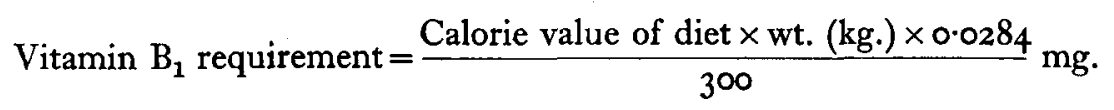

On these diets the nitrogen retention was high $(0 \cdot 237,0 \cdot 178$ and $0.235 \mathrm{~g} . \mathrm{N} / \mathrm{kg} . /$ day). All other diets contained adequate amounts of vitamin $B_{1}$ as judged by this standard.

Table 7. Vitamin $B_{1}$ intake and nitrogen retention of the Dutch group of subjects

\begin{tabular}{|c|c|c|c|c|c|c|}
\hline \multirow[b]{3}{*}{ Subject } & \multirow{3}{*}{$\begin{array}{l}\text { Cowgill's } \\
\text { (1934) } \\
\text { standard } \\
\text { requirement } \\
\text { for } \\
\text { vitamin } B_{1} \\
\text { (mg./day) }\end{array}$} & \multirow{2}{*}{\multicolumn{3}{|c|}{ Vitamin $B_{1}$ intake }} & \multicolumn{2}{|c|}{ Nitrogen retained } \\
\hline & & & & & \multirow[b]{2}{*}{$\begin{array}{l}\text { g. } / \mathrm{kg} \text {. body- } \\
\text { weight } / \text { day }\end{array}$} & \multirow{2}{*}{$\begin{array}{l}\text { As per- } \\
\text { centage of } \\
\text { nitrogen } \\
\text { absorbed }\end{array}$} \\
\hline & & mg./day & $\begin{array}{c}\mathrm{mg} \cdot / \mathrm{kg} . \text { body- } \\
\text { weight } / \text { day }\end{array}$ & $\begin{array}{l}\mathrm{mg} \cdot / \mathrm{I} 000 \\
\text { Cal. intake }\end{array}$ & & \\
\hline J. & $I \cdot 23$ & 0.35 & 0.009 & $0 . I I$ & 0.237 & $2 I$ \\
\hline E. & $\mathrm{I} \cdot 57$ & $2 \cdot 08$ & 0.038 & 0.68 & 0.081 & 20 \\
\hline & I 73 & 0.35 & 0.006 & $0 . I I$ & 0.178 & 22 \\
\hline Z. & $I \cdot 30$ & $2 \cdot 08$ & 0.045 & 0.68 & 0.129 & 25 \\
\hline $\mathrm{K}$. & $\mathrm{I} \cdot 42$ & $2 \cdot 08$ & 0.042 & 0.68 & 0.112 & 25 \\
\hline V. & $1 \cdot 30$ & $2 \cdot 08$ & 0.045 & 0.68 & 0.178 & 37 \\
\hline T. Jr. & $1 \cdot \infty 0$ & 3.56 & 0.079 & $I \cdot 60$ & 0.106 & 24 \\
\hline T. Sr. & $\mathrm{I} \cdot 92$ & $7 \cdot 44$ & 0.158 & $2 \cdot 53$ & $0.14 x$ & 37 \\
\hline d. G. & $I \cdot 5^{8}$ & $5 \cdot 39$ & 0.106 & $I \cdot 60$ & 0.167 & 29 \\
\hline v. d. H. & $\mathbf{I} \times 7$ & $7 \cdot 44$ & 0.177 & $2 \cdot 53$ & 0.156 & 36 \\
\hline B. & 1.84 & $5 \cdot 39$ & 0.100 & $x \cdot 60$ & 0.201 & 37 \\
\hline $\mathrm{T}$ & $\mathrm{I} \cdot \mathrm{Or}$ & $7 \cdot 44$ & 0.203 & $2 \cdot 53$ & 0.195 & 41 \\
\hline v. A. & $1 \cdot 32$ & 4.96 & $0.1 I 0$ & $I \cdot 60$ & 0.222 & 37 \\
\hline $\mathrm{Bg}$ & 1.88 & 0.35 & 0.008 & 0.11 & 0.235 & 23 \\
\hline
\end{tabular}

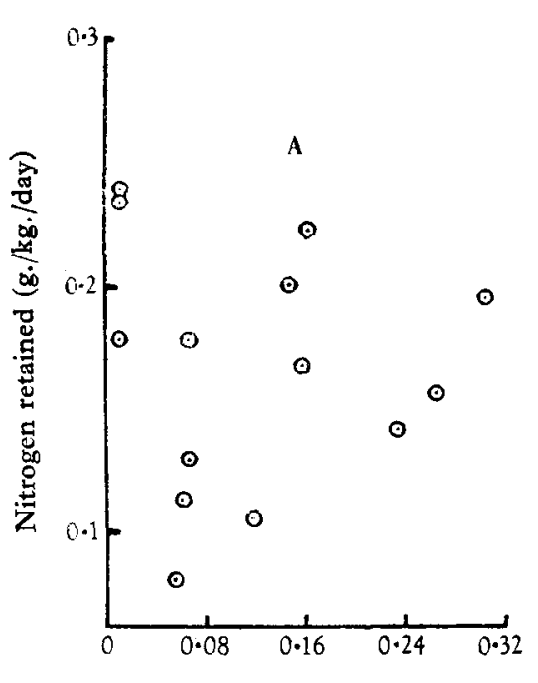

Vitamin $B_{1}$ (mg./kg./day)

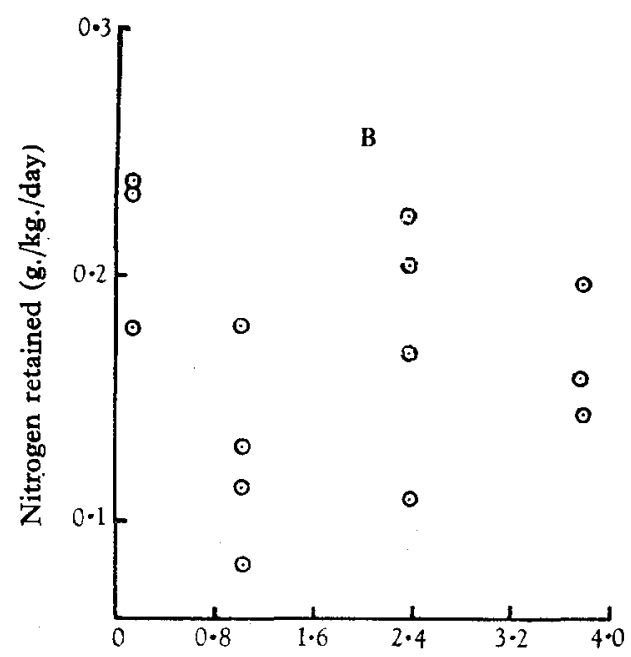

Vitamin $B_{1}$ (mg./I000 Cal./day)

Fig. 9. Relation between vitamin $\mathbf{B}_{1}$ intake expressed as $\mathrm{mg} \cdot \mathrm{kg}$. body-weight/day (A), as mg./1000 Cal./day (B), and nitrogen retention (Dutch series). 
The absolute nitrogen retentions of Group I were, with one exception, in excess of $100 \mathrm{mg}$. N/kg./day, while those of Group II, again with one exception, were below $65 \mathrm{mg}$. $\mathrm{N} / \mathrm{kg}$./day. Although nitrogen retention in absolute values rose with the nitrogen intake, the level of this retention was apparently conditioned by the calorie intake. If the 'efficiency' of the diet is regarded as the percentage of the nitrogen absorbed which is conserved, then those diets which had a high proportion of nonprotein calories were more 'efficient'. There is no conclusive evidence that the metabolic level affects the level of nitrogen retention.

\section{SUMMARY}

I. In emaciated individuals the sign of the nitrogen balance is positive if the intake is above 35 Cal. and $0.17 \mathrm{~g}$. N/kg. body-weight.

2. The absolute amount of nitrogen retained is apparently related directly to the calorie intake provided the nitrogen intake is above the critical level for nitrogenous equilibrium ( $0.17 \mathrm{~g} . / \mathrm{kg}$./day) for the emaciated individual.

3. If the ratio of non-protein to protein calories in the intake is low, nitrogen retention falls. The most efficient ratio for retention at any total calorie intake is apparently above $5: \mathrm{I}$.

4. The metabolic level and the intake of vitamin $B_{1}$ have no definite influence on the level of nitrogen retention.

We wish to thank our Dutch assistants for their help in this investigation. Our thanks are also due to Miss A. W. Watts who was responsible for the dietetic work and to the officers of the Public Health Branch of S.H.A.E.F. (Netherlands Mission) and of the Control Commission for Germany for affording us the opportunities to carry out this work. The Medical Research Council provided funds to cover the expenses of the investigation. The Council of the Royal College of Surgeons released two of us (J. B. and P. H. H.) and the University of Cambridge the other (D. J. B.) to make these studies.

\section{REFERENCES}

Beattie, J. \& Herbert, P. H. (1947). Brit. F. Nutrit. 1, 192.

Council of British Societies for Relief Abroad (1945). Nutrition and Relief Work. London: Oxford University Press.

Cowgill, G. R. (I934). The Vitamin B Requirement of Man. New Haven: Yale University Press.

McCance, R. A. \& Widdowson, E. M. (1942). Spec. Rep. Ser. med. Res. Coun., Lond., no. 235, 3rd reprinting.

Netherlands Food Administration (1 944). Nederlandsche Voedingsmiddeln Tabel. The Hague. 


\section{Appendix}

\section{Composition of diets used}

High-protein diet (H. P.)

This diet was designed to provide $50 \mathrm{~g}$. of nitrogen and about $3100 \mathrm{Cal}$./day with the major part of the nitrogen contained in milk protein.

$\begin{array}{lccc}\quad & \begin{array}{c}\text { Quantity } \\ \text { Constituent }\end{array} & \begin{array}{c}\text { Nitrogen content } \\ \text { (g.) }\end{array} & \begin{array}{c}\text { Energy value } \\ \text { (Cal.) }\end{array} \\ \text { Skim milk powder } & 750 & 43.00 & 2558 \\ \text { Bread } & 40 & 0.47 & 95 \\ \text { Butter } & 5 & - & 39 \\ \text { Eggs } & 100 & 2 \cdot 08 & 156 \\ \text { Corned beef } & 100 & 4 \cdot 00 & 244 \\ \text { Potatoes } & 100 & 0.22 & 65 \\ \text { Vegetables } & 50 & 0.16 & 10 \\ & & 49.93 & 3167\end{array}$

Low-protein diet (L. P.)

This diet was intended to provide half the nitrogen intake of the high-protein diet (H. P.) with a calorie intake of around $3000 \mathrm{Cal}$./day.

$\begin{array}{lccc}\quad & \begin{array}{c}\text { Quantity } \\ \text { Constituent }\end{array} & \begin{array}{c}\text { Nitrogen content } \\ (\mathrm{g} .)\end{array} & \begin{array}{c}\text { Energy value } \\ \text { (Cal.) }\end{array} \\ \text { Skim milk powder } & 300 & 17 \cdot 22 & 1035 \\ \text { Eggs } & 100 & 2 \cdot 08 & 156 \\ \text { Corned beef } & 100 & 4 \cdot 0 & 244 \\ \text { Potatoes } & 450 & 0.99 & 293 \\ \text { Vegetables } & 100 & 0 \cdot 70 & 53 \\ \text { Bread } & 40 & 0 \cdot 47 & 95 \\ \text { Butter } & 5 & -- & 39 \\ \text { Sugar } & 50 & - & 197 \\ \text { Glucose } & 50 & - & 188 \\ \text { Syrup } & 50 & - & 149 \\ \text { Starch porridge } & 47 x & - & 542 \\ & & 25 \cdot 46 & 2991\end{array}$

Starch porridge had the following composition:

$\begin{array}{lr}\text { Corn starch } & \text { rog. } \\ \text { Glucose } & 20 \mathrm{~g} . \\ \text { Water to } & \text { I00 ml. }\end{array}$

Milk-powder diets (M.)

Two milk-powder and glucose diets were used. The low-calorie diet provided approx. I600 Cal. with about rog. nitrogen while the high-calorie diet provided approx. 2200 Cal. and $20 \mathrm{~g}$. nitrogen.

Skim milk powder

Glucose

\begin{tabular}{|c|c|c|}
\hline \multicolumn{3}{|c|}{ Low-calorie diet } \\
\hline $\begin{array}{l}\text { Quantity } \\
\text { (g.) }\end{array}$ & $\begin{array}{c}\text { Nitrogen } \\
\text { content } \\
\text { (g.) }\end{array}$ & $\begin{array}{c}\text { Energy } \\
\text { value } \\
\text { (Cal.) }\end{array}$ \\
\hline I72 & $9 \cdot 85$ & 587 \\
\hline 197 & - & $73^{8}$ \\
\hline 250 & - & \\
\hline & $9 \cdot 85$ & 1613 \\
\hline
\end{tabular}

High-calorie diet

$\begin{array}{ccc}\begin{array}{c}\text { Nitrogen } \\ \text { Quantity } \\ \text { (g.) }\end{array} & \begin{array}{c}\text { Energy } \\ \text { (g.) }\end{array} & \begin{array}{c}\text { value } \\ \text { (Cal.) }\end{array} \\ 344 & 19.7 & \text { II73 } \\ 281 & - & 1054 \\ - & - & - \\ & \text { I9.7 } & 2227\end{array}$


The glucose used in these and all other diets contained in $100 \mathrm{~g}$. the following added synthetic vitamins:

$\begin{array}{lc} & \mathrm{mg} . \\ \text { Vitamin } \text { B }_{1} & \mathbf{1} \cdot 33 \\ \text { Riboflavin } & \mathrm{I} \cdot 33 \\ \text { Nicotinic acid } & 13 \cdot 3 \\ \text { Ascorbic acid } & 33 \cdot 3\end{array}$

\section{Protein-hydrolysate diet (H.)}

This consisted of two foodstuffs-enzymic hydrolysates of meat and casein and glucose.

\begin{tabular}{lccc}
\multicolumn{1}{c}{ Constituent } & Quantity & Nitrogen content & $\begin{array}{c}\text { Energy value } \\
\text { (Cal.) }\end{array}$ \\
Protein hydrolysate & (g.) & (g.) & 458 \\
Glucose & 150 & $18 \cdot 0$ & 1845 \\
Starch porridge & 492 & - & 627 \\
& 545 & - & 2930
\end{tabular}

Mixed diets (Mx.)

The mixed diets given in the Dutch experiments aimed at providing around $3000 \mathrm{Cal}$. and $25 \mathrm{~g}$. N/day. The animal-protein content of the diet was above $70 \%$ of the total protein intake. The following table gives a typical example of such diets.

\begin{tabular}{lccc}
\multicolumn{1}{c}{ Constituent } & $\begin{array}{c}\text { Quantity } \\
\text { (g.) }\end{array}$ & $\begin{array}{c}\text { Nitrogen content } \\
\text { (g.) }\end{array}$ & $\begin{array}{c}\text { Energy value } \\
\text { (Cal.) }\end{array}$ \\
Milk, standard & 1000 & $5 \cdot 12$ & 675 \\
Eggs & 200 & $4 \cdot 16$ & 312 \\
Corned beef & 100 & $4 \cdot 00$ & 244 \\
Beef & 100 & 3.52 & 118 \\
Potatoes & 150 & $0 \cdot 33$ & 97 \\
Vegetables & 100 & 0.20 & 15 \\
Bread & 200 & 2.34 & 476 \\
Butter & 60 & 0.05 & 456 \\
Biscuits & $5 \circ$ & 0.77 & 194 \\
Cheese & 40 & 1.86 & 140 \\
Oatmeal porridge & 250 & 1.68 & 310 \\
Sugar & 15 & - & 62 \\
Tea & 150 & - & - \\
& & 24.03 & 3099
\end{tabular}

The diets used in the German experiments had to be constructed bearing in mind foodstuffs available not only in the institution but in the British Zone for civilian consumption. The diet given below was a standard prison-diet used in the first diet period in the German group.

\begin{tabular}{|c|c|c|c|}
\hline Constituent & $\begin{array}{l}\text { Quantity } \\
\text { (g.) }\end{array}$ & $\begin{array}{l}\text { Nitrogen content } \\
\text { (g.) }\end{array}$ & $\begin{array}{l}\text { Energy value } \\
\text { (Cal.) }\end{array}$ \\
\hline Bread & 336 & $3 \cdot 36$ & 772 \\
\hline Beef & 50 & $I=70$ & 76 \\
\hline Sugar & 41 & - & 162 \\
\hline Flour (mixed rye, oat and wheat) & 33 & $0.5 \mathrm{I}$ & I I 5 \\
\hline Spring onions & 19 & 0.03 & 7 \\
\hline Bacon fat & 4 & - & 31 \\
\hline Potatoes (raw and peeled) & 444 & $1 \cdot 51$ & 386 \\
\hline Lettuce & 600 & $1 \cdot 02$ & 66 \\
\hline \multirow[t]{2}{*}{ Liver sausage } & $4 I$ & $I \cdot I 8$ & I I7 \\
\hline & & $9 \cdot 31$ & $x 732$ \\
\hline
\end{tabular}


Animal protein thus formed about $30 \%$ of the total protein intake.

During the second diet period the intake was raised by $500 \mathrm{Cal}$. from non-protein sources. The protein intake was kept unchanged. In the third diet period the protein intake was raised by adding $25 \mathrm{~g}$. animal protein/day usually as fish (canned pilchards or fresh fish). This raised the animal protein to about $50 \%$ of the total protein intake. The calorie intake rose by about $100 \mathrm{Cal}$. In the fourth diet period the protein content of the diet was raised by $20 \mathrm{~g}$. protein/day usually as fish but the total calorie intake was maintained at the level of the third period. Thus the percentage of animal protein rose to almost $70 \%$ of the total protein intake. During the fifth diet period the total calorie intake was raised by about $35^{\circ} \mathrm{Cal}$. but the total protein intake was maintained constant at the level of the fourth period.

\title{
Nutrition of Domestic Rabbits
}

\section{The Effect of Nutrition on the Carcass Composition of the Rabbit}

\author{
By J. C. D. HUTCHINSON \\ Small Animal Breeding Station and Department of Poultry Nutrition, \\ Animal Nutrition Institute, School of Agriculture, Cambridge
}

(Received I 5 August 1947)

It has long been known that different rates of growth when caused by differences in the amount of food eaten proföundly, affect the carcass composition of animals. Detailed studies on farm animals have been made by Moulton, Trowbridge \& Haig (1922) for cattle, by Vergés (1939) for sheep and by McMeekan (1940a, b, $c$ ) for pigs. Feeding ad lib. favours rapid growth of the late-developing parts of the animal, e.g. anatomically the loin or, chemically the deposition of fat, and therefore gives rapid maturity. Undernutrition stunts these late-developing parts because such food as is available for growth is used preferentially for those parts of the animal which are physiologically most important such as the skull and viscera. Undernutrition therefore produces a 'primitive' or late-maturing type of animal.

Many experiments have been carried out in which the effect of the qualitative nature of the ration on body composition has been investigated by chemical analysis of the whole carcass. In most cases the paired-feeding method was employed. With this technique the faster growing animal of a pair receives less food in relation to its requirements than its mate, and in general tends to lay down less fat in proportion to protein. This is especially true in the later stages of an experiment when one animal of a pair is considerably heavier than the other. Thus Mitchell \& Hamilton (1936) found that, with pigs and rats, as the protein level of the ration was raised to about $25 \%$, the proportion of fat to protein laid down decreased. Johnson, Hogan 